\title{
MIĘDZY AKTEM ŚWIADOMOŚCI A WYPOWIEDZIĄ. TECHNIKA STRUMIENIA ŚWIADOMOŚCI JAKO METAFORA SZTUKI
}

\author{
Słowa kluczowe: strumień świadomości, symbol, Julian Przyboś
}

Keywords: stream of consciousness, symbol, Julian Przyboś

Pamięci prof. Kazimierza Bartoszyńskiego, pierwszego czytelnika tego tekstu, z niegasnąca wdzięcznościa

\section{Strumień świadomości}

Często przyjmuje się założenie, że wypowiedź literacka tym odróżnia się od wypowiedzi nieliterackiej, iż spełnia funkcję estetyczną, co wynika z wewnętrznej organizacji tej wypowiedzi, przewyższającej potrzeby komunikacji, to znaczy z tzw. „organizacji naddanej”. Kiedy zastanawiałam się nad adekwatnością tej definicji do obserwowanych faktów literackich, zwróciły moją uwagę teksty, posługujące się techniką strumienia świadomości.

Strumień świadomości jest formą podawczą, przedstawiającą akty świadomości, a nie obiekty, zdarzenia i zjawiska, które mogą być jej przedmiotem ${ }^{1}$. Technika ta mogła powstać tylko w tym okresie kultury, w którym doszło do powszechnego wyraźnego rozróżnienia świata i jego ujęcia w świadomości: w czasach Schopenhauera, Nietzschego, Bergsona i Husserla ${ }^{2}$. Fenomenologiczne rozróżnienie aktu świadomości i przedmiotu tego aktu jest kluczem do rozumienia

\footnotetext{
${ }^{1}$ Świadomość, jej właściwości i treści pojmuję w duchu filozofii Edmunda Husserla (Badania logiczne, Medytacje kartezjańskie).

${ }^{2}$ Badania psychologiczne nad strumieniem świadomości prowadził William James, a filozoficzne - Edmund Husserl. Pierwszą powieścią, w której użyto techniki strumienia świadomości, było opowiadanie Edouarda Dujardina Wawrzyny już ścięto (polski przekład - Jacek Trznadel, 1971), za najważniejsze osiągnięcia tej formy uważa się powieści Virginii Woolf, Jamesa Joyce'a i Williama Faulknera.
} 
techniki strumienia świadomości: przedstawia ona właśnie akty (wraz z ich treścią), a nie ich przedmioty.

Akty te są różnego typu: spostrzeżenia pochodzące ze zmysłów zewnętrznych (wzroku, słuchu, dotyku, smaku, powonienia), ale także spostrzeżenia wewnętrzne (odczucia bólu, smutku, radości, senności, ożywienia, zmęczenia itd.) ${ }^{3}$, wspomnienia, przywołania kiedyś doznanych wrażeń, a także wyobrażenia, nadto myśli (czymkolwiek by nie były) i wypowiedzi (własne i czyjeś, słyszane, przypominane). Wiadomo, że kontrola świadomości nad biegiem strumienia wrażeń prawie całkowicie ustaje podczas snu, że może być rozluźniana w swobodnym marzeniu i zacieśniana w rygorystycznie prowadzonym rozumowaniu. Zajmujący się tą techniką Robert Humphrey wyróżnił cztery techniki strumienia świadomości. Zalicza do nich, co warte uwagi, także opis wszechwiedzący, jako najbardziej uporządkowany przez czynniki ingerujące w bieg życia świadomości, a następnie pośredni monolog wewnętrzny, bezpośredni monolog wewnętrzny, i w końcu postać najsilniejszą: soliloquium. Ostatni wymieniony sposób przedstawienia tzw. świata przedstawionego w powieści, najbardziej zbliżony do realnego życia świadomości, polega na bezpośredniej prezentacji świadomości wybranego bohatera, w której odbiorca ogląda wszystko, co się w niej pojawia, a zatem także i świat - dla odbiorcy przedstawiony, dla bohatera: ten, w który jest zanurzony, gdzie aktywnie postrzega i przetwarza postrzeżenia. Ta postacią techniki strumienia świadomości będę się zajmować przede wszystkim ${ }^{4}$.

Rozważmy teraz kilka właściwości funkcjonowania świadomości, które będą nam przydatne w rozważaniu dzieła sztuki. Świadomość działa przynajmniej na dwóch poziomach. Po pierwsze jest świadomością pewnych wrażeń i myśli. Do właściwości świadomości ludzkiej należy bardzo ważna własność, opisana przez Husserla: to, że świadomość sama rozpoznaje różnice pomiędzy swoimi aktami. Na przykład rozróżnia między spostrzeganiem jakiegoś obiektu a tego obiektu przypominaniem, choćby to wspomnienie $\mathrm{z}$ fotograficzną dokładnością odpowiadało realnemu aktualnemu postrzeganiu. Do właściwości świadomości należy i to, że jest ona świadoma tego, że wszystkie jej akty są właśnie jej aktami, że należą do niej samej, że w niej właśnie się pojawiają. Na tym funduje się poczucie tożsamości człowieka. Jednocząca siła świadomości w konsekwencji jest w stanie ze wszystkich wrażeń wewnętrznych złożyć wizerunek świadomego „ja”, a ze wszystkich wrażeń zewnętrznych złożyć obraz tego, co świadome ,ja” nazywa światem. Własności te opisali - w różny sposób - Kartezjusz, Kant, Schelling i Husserl.

${ }^{3}$ W Dodatku do Badań logicznych Husserl rozważa rozumienie terminów: „spostrzeżenie wewnętrzne”, ,spostrzeżenie zewnętrzne” (Edmund Huserl, Badania logiczne, vol. II/II, trans. Janusz Sidorek et Andrzej Półtawski (Warszawa: Wydawnictwo Naukowe PWN, 2000), 267-295).

${ }^{4}$ Robert Humphrey, „Strumień świadomości - techniki”, trans. Stefan Amsterdamski, Pamiętnik Literacki, no. 4 (1970). Idem, Stream of Consciousness in the Modern Novel (Berkeley and Los Angeles, 1953). 
Po drugie - na metapoziomie - świadomość może uczynić przedmiotem swego postrzegania dowolną treść, którą ujmuje na pierwszym poziomie. Świadomość zatem (przynajmniej u ludzi dojrzałych) bywa samoświadomością: nie tylko sobie coś uświadamiany, ale możemy sobie także uświadomić, że to właśnie sobie uświadamiany. Nie na tym jednak polega siła świadomości, nie na ujmowaniu samej siebie aktem samoświadomości, ale - wedle określenia Manfreda Franka, badającego tę problematykę zwłaszcza u Schellinga - na „bezszczelinowej” świadomości własnej zawartości. Świadomość, za Schelligiem, jest przez Franka ujmowana jako całość jednocząca to, co zmienne, płynące i zróżnicowane (strumień przeżyć wewnętrznych i zewnętrznych), i to, co trwające, a zarazem zdolne do ukierunkowywania własnych aktów, rządzące owym strumieniem i w nim się realizujące ${ }^{5}$.

\section{Czy zapis strumienia świadomości jest tekstem i czy jest wypowiedzią?}

Utrwalony w słowie (zwerbalizowany) przebieg strumienia świadomości będę nazywać (w odróżnieniu od samego zjawiska psychologicznego) - zapisem strumienia świadomości. Technikę budowania tekstu literackiego, naśladującą taki zapis, będę nazywać techniką strumienia świadomości.

Czy w odniesieniu do zapisu strumienia świadomości można użyć pojęcia tekstu? Jeśli rozumieć przez tekst jakikolwiek ciąg zdań, posiadający początek i koniec, który z jakiegoś powodu został spisany (wygłoszony), a jego percepcja ma służyć jakiemuś celowi, to taki zapis może być tekstem. Na przykład może być tekstem zapis słów szeptanych przez pacjenta w malignie, które spisuje lekarz badający zjawiska halucynacji. Jeśli jednak będziemy rozumieć przez tekst taki ciąg słów posiadających znaczenie, który jest uporządkowany wewnętrznie, budowany zgodnie $\mathrm{z}$ regułami rozwijania wypowiedzi (najważniejszą jest tutaj nadanie właściwej struktury tematyczno-rematycznej), mający wyodrębniony strukturalnie początek i koniec, wskazany przez reguły delimitacji tekstu, to zapis strumienia świadomości w oczywisty sposób nie jest tekstem.

Zapis strumienia świadomości przedstawia coś nieuporządkowanego: kapryśny bieg czyichś wrażeń i myśli. Czy można zbudować tekst literacki na wzór strumienia świadomości? Technika strumienia świadomości jest właśnie taką próbą ${ }^{6}$.

${ }^{5}$ Manfred Frank, Świadomość siebie i poznanie siebie, trans. Zbigniew Zwoliński (Warszawa: Oficyna Naukowa, 2002), 79.

${ }^{6}$ Oczywiście, przedstawione tak zdania mogą mieć jakiś sens psychologiczny, to znaczy ukazywać kształt czyichś przeżyć i odsłaniać czyjąś psychikę. Pojawi się tu pewnego typu uporządkowanie, lecz nie w planie wyrażania, ale w planie treści. Pochodzi ono tylko z faktu, że przedmiotem przedstawienia jest jakaś jedna osoba, która jest pewnego typu jednością w sensie psychicznym, w planie emocjonalnym i mentalnym. Nie jest to uporządkowanie naddane, o jakim zwykle się chyba myśli, gdy mówi się o tekście literackim. 
Odsuńmy kwestię sensu i celu tak zbudowanego tekstu i zastanówmy się, czy można go nazwać wypowiedzią literacką. Odpowiedź może się wydać paradoksalna. Jeśli to w ogóle ma być wypowiedź, to właśnie musi to być wypowiedź literacka.

Dlaczego? Zapis strumienia świadomości nie jest ani opowiadaniem, ani opisem (każda $\mathrm{z}$ tych form ma swoje zasady organizacji w sferze konstrukcji zdań i komponowania zdań w całość), nie jest także monologiem wewnętrznym (i ten ma swoje zasady organizacji), tym bardziej nie jest monologiem wypowiedzianym. W ogóle nie jest wypowiedzią - ponieważ nie zakłada żadnego słuchacza. Tym, co czyni z wygłaszanych przez kogoś zdań (w mowie czy w piśmie) wypowiedź, jest dobór i uporządkowanie zdań w ciągu od pierwszego do ostatniego, oraz dobór i uporządkowanie słów w zdaniu, które dokonuje się ze względu na możliwość zrozumienia kolejnych zdań przez odbiorcę. Chodzi tu o uporządkowanie w planie linearnym, w planie wyrażania, rozumianym jako ciąg słów i zdań. Zapis strumienia świadomości nie wprowadza takiego uporządkowania, ponieważ przebieg wrażeń i myśli pojawiających się w świadomości nie jest ukierunkowany na zakomunikowanie komukolwiek czegokolwiek. Mimo to odbiorca jest w stanie „zrozumieć” (wstawiam to słowo w cudzysłów, ponieważ chodzi o inny typ rozumienia) tekst odzwierciedlający strumień świadomości, który nie jest wypowiedzią, jeśli zrekonstruuje powód, dla którego nie zaprezentowano mu wypowiedzi, lecz właśnie coś, co wypowiedzią nie jest. Wymaga to ujęcia tekstu na metapoziomie, na którym to, co nie było wypowiedzią, staje się nią w tym sensie, że zyskuje plan, w którym mogłoby znaczyć $^{7}$.

Żeby ułatwić Czytelnikom zrozumienie stawianego przeze mnie problemu, przywołam przykład z dziedziny sztuk plastycznych.

\section{Działanie artystyczne jako akt świadomości wyróżniający dowolny zbiór elementów przez umieszczenie w „ramie estetycznej”. Ready-made}

W sztuce plastycznej w obrębie pop-artu zaistniał kierunek zwany ready-made, pierwotnie znany w dadaizmie. Artysta-plastyk nie malował ani nie rzeźbił, nawet nie fotografował, lecz brał gotowy przedmiot (np. puszkę coli, krzesło, durszlak, miskę z praniem) i eksponował jako dzieło sztuki. Działanie to oparte jest na prostym pomyśle: po co robić dzieło sztuki, jeśli jest już gotowe? Wokół, w świecie, znajduje się wiele rzeczy, które można pokazać jako zdolne do budzenia przeżycia estetycznego. Dawni artyści takie rzeczy malowali: pejzaże, twarze,

\footnotetext{
${ }^{7}$ Możemy sobie na przykład wyobrazić tekst naśladujący zapis strumienia świadomości, który zyskuje sens, dzięki wprowadzeniu jakiejś ramy metatekstowej, choćby danej w tytule, np. „Marzenie nocne”, „Fantazja konającego”, „Wyznanie pobitego”.
} 
misy z owocami, robaczywe jabłka, połówki zajęcy, graty i rupiecie. Ale po co je malować lub fotografować, skoro można je po prostu wskazać? Jeśli artysta to ten, który umie coś wyodrębnić ze zwykłej rzeczywistości i ukazać sobie oraz innym jako coś artystycznego, to artysta jest każdy, kto wskaże na przedmiot i sprawi, że zaprezentuje się jako przedmiot artystyczny. Czy powinna to być rzecz szczególna, czy powinien jej przysługiwać np. walor piękna, szczególnego porządku wewnętrznego, niezwykłości? Zdaje się, że potencjalnie walor ten ma każdy dowolny przedmiot, ładny czy brzydki, funkcjonalny czy niefunkcjonalny, nowy czy zniszczony, czytelny w swej budowie i nieczytelny.

Co się zmieniło, gdy się patrzyło na balię jako na balię, a potem na balię jako na przedmiot artystyczny? Z pozoru nic, a jednak: „Zamieniło się wszystko”. Przeniesienie (mentalne) balii w sferę przedmiotów artystycznych, umieszczenie jej w „ramie estetycznej” ${ }^{8}$ radykalnie zmienia kontekst, w którym ten przedmiot się pojawia (są to inne przedmioty, już kiedyś zaliczone do artystycznych) i tryb, w jakim świadomość go rozważa. Nie jest to już przedmiot użytkowy, dobrze lub źle wykonany, wygodny lub niewygodny w użyciu, a nawet ładny lub brzydki. Jest to trójwymiarowy przedmiot z metalu (czy innego materiału), który do niedawna służył do czegoś, a teraz stał się swobodnie istniejącą w przestrzeni artystycznej bryłą, rzeźbą, uwolnioną z pęt funkcjonalności, i tylko niejako przy okazji demonstrującą swój dawny status misy do prania lub kąpieli. Wprowadzono go w sferę, gdzie przedmiot nie służy już niczemu, lecz temu, by był oglądany sam dla siebie i dla wszystkich swoich własności. Przypadkowe obtłuczenie czy wygięcie, rysa lub jakakolwiek inna cecha staje się teraz czymś potencjalnie znaczącym, godnym rozważenia, elementem artystycznej kompozycji ${ }^{9}$.

Wydaje mi się, że prezentację przez artystę takich przedmiotów można opisać jako działanie na trzech poziomach świadomości: 1) ja to widzę i doznaję pewnych uczuć i myśli związanych z tym obiektem; 2) jestem świadomy, że to widzę, i wyróżniam ten akt widzenia spośród innych swoich aktów jako posiadający

${ }^{8}$ Rama estetyczna oznacza przeniesienie w obszar, w którym przedmioty percypowane są na sposób estetyczny, to jest jako przedmioty, mogące stać się podstawą przeżycia estetycznego. Przeżycie estetyczne rozumiem wedle ujęcia: Stanisław Ossowski, Wybór pism estetycznych, ed. Bohdan Dziemidok (Kraków: Universitas, 2004). Vide Władysław Tatarkiewicz, Dzieje sześciu pojęć: sztuka, piękno, forma, twórczość, odtwórczość, przeżycie estetyczne (Warszawa: PWN, 1976).

${ }^{9}$ Dyskusję problemu sposobu istnienia przedmiotu sztuki, który radykalnie wykracza poza przyjęte konwencje przeprowadza Maria Gołaszewska, Estetyka i antyestetyka (Warszawa: Wiedza Powszechna, 1984), w rozdziałach: 5. Dzieło, 6. Odbiorca. Znajduje wyznaczniki wszelkiego dzieła, także awangardowego, należącego do tzw. antysztuki. Są nimi: a) bycie rezultatem procesu twórczego, nakierowanym na kreację czegoś, co jest nakierowane na ludzką potrzebę dystansu estetycznego wobec świata (jedyną ich racją istnienia jest potrzeba percepcji), b) mają charakter przedmiotów zobiektywizowanych, intersubiektywnych, istniejących poza świadomością twórcy c) wpisują się - choćby przez negatywne nawiązanie - do już istniejących tworów sztuki (123-124). 
szczególne walory (pierwszy metapoziom); 3) prezentuję ten przedmiot odbiorcy, aby on ufundował na nim swój własny akt estetyczny (drugi metapoziom). Od strony widza prezentacja taka ma również trzy poziomy: 1) to jest znany mi przedmiot (np. balia do prania); 2) ten przedmiot został przez kogoś w z jakiegoś powodu wyróżniony (pierwszy metapoziom); 3) cel tego wyróżnienia to cel estetyczny (drugi metapoziom). Widz, który rozważa ten przedmiot, na pierwszym poziomie widzi go jako użytkowy. Potem dokonuje przeniesienia go na metapoziom: ujmuje go jako wybrany przez kogoś i widziany przez niego w pewien szczególny sposób, wynikający z wrażliwości tej osoby, a także ze szczególnych walorów tego przedmiotu. Na kolejnym, drugim już metapoziomie, widzi ten przedmiot jako tak właśnie pomyślane przez kogoś dzieło sztuki. Być może jest i jeszcze jeden, trzeci już metapoziom, na którym widz ujmuje ten przedmiot jako pewnego typu propozycję budowania (konstruowania) przedmiotów sztuki, czyli jako koncepcję uprawiania sztuki.

Najprostszy przedmiot można eksponować i kazać oglądać w ten sposób. Inna sprawa, że tak złożone wielopoziomowe widzenie dzieła sztuki jest dla większości widzów niedostępne. Dlatego zaprzeczają oni, jakoby tego typu przedmioty mogły być dziełami sztuki. „Estetyczności” upatrują w czym innym: w wewnętrznym zorganizowaniu lub wyposażeniu w określoną jakość estetyczną (piękno, tragizm, wzniosłość) lub w stosunku przedmiotu sztuki do rzeczywistości (np. w mimetyczności). Można jednak starać się pokazać, że „estetyczność” polega na czym innym: na operacji świadomości nad jakimkolwiek aktem świadomości. Na przykład nad spostrzeżeniem czegokolwiek. Sama przedstawiana rzecz nie musi posiadać jakiejkolwiek dającej się wyróżnić jakości estetycznej. Przeniesienie jej percepcji na opisane wyżej metapoziomy świadomości nadaje jej walor estetyczny bez względu na jej uposażenie. Może to być rzecz w ogóle niezłożona, na którą składa się pojedyncza cecha: na przykład kula, kropka, snop światła lub pojedynczy dźwięk o nieokreślonej wysokości, np. szum, a nawet cisza.

Oczywiście, może to także być rzecz bardzo wewnętrznie złożona. Jak sądzę, jest ona również odbierana na kilku poziomach świadomości, tak jak próbuję opisać. Przypuszczam, że jej dodatkowe, „naddane wewnętrzne zorganizowanie” służy nie do tego, żeby ukonstytuować tę rzecz jako przedmiot estetyczny, ale żeby ją po prostu wyodrębnić spośród innych przedmiotów jako przeznaczoną do oglądu estetycznego. Zwłaszcza jest to istotne w przypadku tekstu literackiego, który musi się jakoś wyróżnić spośród innych tekstów. Walor estetyczny może mieć jednak tekst zupełnie prosty, a także zupełnie nieuporządkowany. Przedmiotem oglądu estetycznego i źródłem przeżycia estetycznego staje się przecież w końcu nie sama złożoność przedmiotu, ale ten przedmiot jako całość - całość złożona (lub właśnie niezłożona, prosta). 


\section{Zapis strumienia świadomości jako wypowiedź literacka typu ready-made}

Posługiwanie się w literaturze techniką strumienia świadomości przypomina pod pewnym względem kierunek ready-made. Wystarczy wybrać jakiś fragment tej swoistej rzeczywistości wewnętrznej, jaką jest płynący zawsze strumień wrażeń, myśli i wspomnień, wyodrębnić go, utrwalić w słowie - i - gotowe ${ }^{10}$. Jest już zrobione.

Co się dzieje? Akt świadomości wycina dowolny fragment strumienia świadomości. Ujmuje go w słowach, załóżmy, że w taki sposób, który go nie przekształca. Niech słowa będą zupełnie przezroczyste, niech odzwierciedlają bezpośrednio życie świadomości na przestrzeni jakiegoś czasu. Jak powiedzieliśmy, strumień świadomości podlega różnym fluktuacjom, na ogół rządzą nim luźne skojarzenia, wywoływane przez rozmaite bodźce. Częściowo - lecz tylko częściowo - świadomość sama steruje swoją aktywnością. Tekst wiernie odzwierciedlający strumień świadomości, taki, który nie wprowadza żadnego ładu w nieokiełznany strumień wrażeń i myśli, jest odbierany jako chaotyczny, niezorganizowany, można by zatem powiedzieć: niezrozumiały. Ktoś, kto w życiu codziennym opowiadałby o wszystkim, co „przyszło mu do głowy”, bez żadnej selekcji i bez żadnej próby uporządkowania wypowiedzi ze względu na wiedzę i postęp wiedzy u słuchacza, zostałby niechybnie uznany za wariata. Prezentacja takiego tekstu w innej przestrzeni: wypowiedzi artystycznych radykalnie zmienia go jakościowo, nawet jeśli założymy, że strumień świadomości nie został poddany żadnej artystycznej obróbce.

${ }^{10}$ Pomijam tu zagadnienie przenoszenia treści świadomości w sferę językową - jako bardzo złożone. Dla potrzeb tego wywodu wystarczy, że przyjmiemy, iż przynajmniej w niektórych przypadkach pojawiaja się w świadomości zdania, które moga zostać przeniesione do tekstu literackiego bez żadnego przetworzenia: „Obrawszy sobie miejsce jak najbardziej sprzyjające skupieniu ducha nad samym sobą, przygotuj przybory do pisania. Wprowadź się w stan bierny, odbiorczy, jak dalece stać cię na to będzie. [...] Zacznij szybko pisać bez ustalonego tematu, tak szybko, aby nic nie zachować w pamięci i nie dopuścić do siebie pokusy odczytania tego, coś dotąd napisał. Pierwsze zdanie przyjdzie ci łatwo, prawdą jest bowiem, że w każdej sekundzie jest jakieś zdanie obce naszej myśli świadomej, domagające się ujawnienia. Dość trudno powiedzieć coś bliższego na temat następnego zdania; niewątpliwie to zdanie uczestniczy równocześnie w naszej działalności świadomej i w innej, jeśli się przyjmie, że fakt napisania pierwszego zdania jest $\mathrm{w}$ minimalnym stopniu percypowany. Co to cię zresztą obchodzi? Na tym głównie polega znaczenie gry surrealistycznej. [...] Ciągnij dalej, jak długo zechcesz. Zdaj się na niewyczerpane źródło podszeptu”. André Breton, „Manifest surrealizmu”, in Surrealizm. Teoria i praktyka literacka. Antologia, trans. et ed. Adam Ważyk (Warszawa: Czytelnik, 1976), 81). Kwestię ekspresji doświadczenia wewnętrznego w języku omawiam w swojej książce: Człowiek $i$ doświadczenie wewnętrzne. Późna twórczość Mickiewicza i Stowackiego (Warszawa: Wydawnictwo UKSW, 2009), zwłaszcza w rozdziale III: Jaźń wobec świata zewnętrznego. W prowadzonym tu wywodzie chodzi mi jedynie o to, że dana treść świadomości, np. jakieś pojawiające się w niej zdanie, może zostać przez tę samą świadomość tak ujęte, że staje się czymś jakościowo zupełnie różnym, nie przez zmianę treści, lecz przez sam sposób ujmowania. 
Przede wszystkim akt świadomości, który wycina fragment strumienia świadomości i prezentuje go odbiorcom literatury - podobnie jak się to działo w przypadku przedmiotów ready-made - tworzy ramę estetyczną, w której rzecz ta ma swój początek, koniec i funkcję estetyczną. Wystarcza sam akt wyodrębnienia, któremu jakby towarzyszy gest: to jest przedmiot sztuki, czynię to godnym uwagi w takiej postaci, w jakiej jest.

Przyjrzyjmy się bliżej tak zaistniałemu tekstowi.

Przede wszystkim sam akt wskazania na określony wycinek strumienia świadomości przenosi go już na wyższy poziom świadomości, gdzie jest rozważany, przez tę samą lub inną świadomość. Coś, co było do tej pory nieskrępowanym życiem świadomości, staje się przedmiotem oglądu, rozważania. Akt świadomości czyni ten fragment strumienia świadomości - przedmiotem świadomości.

Czy zatem dochodzi do uprzedmiotowienia, do unieruchomienia? Niekoniecznie. Świadomość ogląda tutaj strumień świadomości, takim, jakim jest. Jest to działanie świadomości na metapoziomie.

Rozważmy teraz świadomość, która ogląda siebie samą (a nie inną świadomość przedstawioną w zapisie strumienia świadomości). W moim przekonaniu wejście na ten poziom i prowadzenie na tym poziomie werbalizacji swoich doznań - bez względu na to, czy mamy do czynienia z techniką strumienia świadomości czy jakąkolwiek inną techniką - odpowiada pozycji podmiotu mówiącego w liryce (tak zwanej osobistej). Mówiąc o werbalizacji mam na myśli wszelkie użycie języka, także metaforycznego. Już samo wejście na ten poziom może być dla świadomości źródłem satysfakcji. Następnie świadomość decyduje, aby ukazać ten zwerbalizowany fragment przebiegu swoich doznań jako przedmiot estetyczny, czyli jako przedmiot, który może posłużyć innemu człowiekowi do ufundowania przeżycia estetycznego. Na tym poziomie, który według mnie odpowiada poziomowi działania podmiotu czynności twórczych, mogą być wprowadzone pewne decyzje dotyczące obróbki zapisu strumienia świadomości, opisane uprzednio jako montaż i wycinanie, a także decyzje dotyczące wersyfikacji lub wprowadzenia elementów narracyjnych czy opisowych.

Sądzę, że każda wypowiedź literacka posiada ten właśnie drugi metapoziom - który poetyka opisuje jako poziom autora wewnętrznego lub podmiotu czynności twórczych - i ten właśnie metapoziom, nadbudowany nad prymarnym sensem każdej wypowiedzi, decyduje o zaistnieniu literackości. Zapis strumienia świadomości, ukazany w tekście literackim, nie posiadający żadnej organizacji naddanej, nie będący nawet wypowiedzią, a więc nie posiadający żadnej organizacji, może się stać wypowiedzią literacką, o ile tekst zostanie wyposażony w ów metapoziom ${ }^{11}$.

${ }^{11} \mathrm{~W}$ dużych formach, wykorzystujących technikę strumienia świadomości, obserwuje się jednak uporządkowanie wewnętrzne, które nie płynie z opisanych wyżej czynności, lecz ufundowane jest na zupełnie innych podstawach. Rzecz ta, arcyciekawa i domagająca się dłuższych badań, w niniejszym szkicu nie może być rozwijana. 
Przejawianie się tego metapoziomu śledzę w liryce stosującej technikę strumienia świadomości, ponieważ utwory ją stosujące (w których nie ma organizacji naddanej na poziomie prymarnym lub jest ona bardzo osłabiona), pozwalaja wygodnie obserwować to zagadnienie.

\section{Operowanie techniką strumienia świadomości w poezji na przykładzie liryki Juliana Przybosia}

Praca świadomości i metaświadomości kojarzy się najczęściej z filozofią, naukami ścisłymi, rzadziej z poezją. Jednak złożona praca świadomości jest nieodłącznym składnikiem każdej sztuki, nawet tej posługującej się natchnieniem lub pozornie wyzbywającej się wszelkiej kontroli, tak jak w notacji strumienia świadomości.

Wiele fragmentów cyklu Juliana Przybosia Pióro z ognia to notacja mikrozdarzeń poetyckich, czyli zapis stanów wewnętrznych podmiotu (może się on także wczuwać w stany innych osób) ${ }^{12}$.

Wprowadźmy w obszar naszych świadomości Niklowe kótko, pisane, jak większość utworów w tym cyklu, prozą poetycką:

I szarpnąwszy za sznurek wypruty z czerwieni wprawiła w wir frygę, buczącą kolor biały, a cichnącą jak tęcza tak lekka, iż nawlekłszy ją na igłę uszyłaby powietrze, przez które przeniesiono dopiero co irysy i którędy przeszło spojrzenie ukochanego.

Wystarczy okręcić się na pięcie, aby spod powiek sypnęły się rozpryśnięte gwiazdeczki, zieleniejące i żółte, powiększone we łzie,

a ze zgiętego grzbietu - dźwięk dzwonka! - zbiegły elektryczne ciarki jak wtedy, kiedy aby ukryć zmieszanie, zaczyna szalony taniec stóp dygocących na pedale maszyny.

Niech wzleci rozpędzona niklowym kółkiem w elewacji radości! Ukochany, nieświadomy siebie, zbliża się kontrolując pracownię, z jego trzcinowej laski bije niewidoczna fontanna różowa i złota

i czarna, gdy dotyka jej pokłutych palców

[Sytuacje liryczne, $110^{13}$.

Co tu się dzieje? Można by pokusić się o rekonstrukcję zdarzeń w planie świata przedstawionego (gdyby o jego przedstawienie chodziło). $Z$ dużym prawdopodobieństwem tę mikrohistorię można by opowiedzieć tak: Szwaczka pracująca przy maszynie do szycia już wie, że ukochany za chwilę do niej podejdzie,

${ }^{12}$ Związek techniki strumienia świadomości z liryką, na tle typologii rodzajów literackich, przedstawiam w pracy: „Liryczność a poznanie wewnętrzne”, in Liryczność - w kręgu problemów estetyki, teorii $i$ historii literatury, ed. Bernadetta Kuczera-Chachulska, Ewangelina Skalińska (Warszawa: Wydawnictwo UKSW, 2013), 153-186.

${ }^{13}$ Wiersze Juliana Przybosia cytuję według wydania: Julian Przyboś, Sytuacje liryczne, intr. Edward Balcerzan, ed. Edward Balcerzan, Anna Legeżyńska (Wrocław: Ossolineum, 1989). 
bo już powietrze się zmieniło od zapachu przyniesionych przez niego kwiatów i od jego spojrzenia, bo już wcześniej słyszała dźwięk dzwonka do drzwi (lecz brzmi w niej jeszcze, pobudzając zmysłowy dreszcz). Nie odwraca się jednak, lecz zgięta nad maszyną wprawia w nieprawdopodobnie szybki ruch niklowe koło maszyny, ujawniając radość. Koło zaczyna się obracać tak szybko, że buczy jak dziecinny bąk, który, choć malowany w różne kolory, przybiera kolor biały, a dopiero zwalniając, ujawnia kolory tęczy. Ukochany przybliża się i ujmuje jej rękę, dotykając pokłutych palców, których dziewczyna zapewne się wstydzi i które mogą ją boleć przy dotknięciu.

Przyboś nie zmienia statusu rzeczy, które są postrzegane - są to nadal istniejące i widziane bardzo wyraźnie przedmioty: kółko poruszające mechanizm maszyny do szycia, wprawione w ruch przez zakochaną dziewczynę, jej ręce, palce, nogi poruszające pedał, szykowny ukochany, który przychodzi do jej pracowni $\mathrm{z}$ modną wtedy trzcinową laską. Aczkolwiek plan metaforyczny tego fragmentu poetyckiego wydaje się dość złożony, plan zewnętrznych wrażeń sensualnych, na których opiera się złożona metaforyka, ściśle trzyma się zasad widzenia znanych z fizyki i zasad reakcji emocjonalnych znanych z psychologii. Światło białe, jak poucza fizyka, jest w istocie mieszaniną światła o różnych barwach, czego dowodzi rozszczepienie promienia słonecznego na wszystkie kolory tęczy w pryzmacie i o czym może się przekonać każde dziecko, rozpędzając dziecinną zabawkę frygę, która obracając się coraz prędzej, staje się coraz bielsza. Człowiek, który bardzo na coś czeka i bardzo czegoś pragnie, odwleka nieraz moment spełnienia marzenia lub pozornie go unika, niejako odwracając się od źródła swego szczęścia. Radość objawia się erupcją energii, miłość wyostrza zmysły, a miłość zmysłowa objawia się dreszczem. To wszystko prawda, lecz nie o tym mowa. W planie świadomości dziewczyny wszystko dzieje się trochę inaczej. Najpierw wprawione jest w ruch kółko, które staje się przedziwną jednością tęczy i białego światła. Potem powstaje chęć (powstrzymana), by obrócić się i ujrzeć tego, kto nadchodzi. Potem dziewczyna zaczyna odczuwać dreszcz emocji, dany jej pod postacią wspomnienia niedawnego dzwonka, który budzi, zapowiada, domaga się otwarcia drzwi, zwiastuje zmianę. Nie na darmo trwa w niej ten dźwięk, przez nią jakby wybrany, powtórzony i zwielokrotniony wprawieniem w ruch maszyny. Potem ktoś (ona sama) daje sobie przyzwolenie na ruch, który już wykonała i na wyzwolenie radości. Mężczyzna-czarodziej, nieświadomy mocy, podchodzi do dziewczyny, w której w ciągu kilku chwil dokonały się zasadnicze zmiany. Jej maszyna jest w stanie „szyć powietrze”, ponieważ ona sama dokonała już pewnych wyborów i nadała kształt sobie i swojemu życiu. On pozostaje jeszcze nieświadomy, ale ona już wkroczyła w inną przestrzeń. Niklowe kótko nie odwzorowuje znanych wszystkim praw fizyki, lecz rekonstruuje niepowtarzalną logikę powiązań świata wewnętrznego i zewnętrznego, które nieustannie przenikają się, stając się niepowtarzalną dynamiczną całością. 
Przyboś nie przekształca tu zawartości świadomości swego podmiotu lirycznego, treści spostrzeżenia. Pracuje na poziomie wyższym, na którym świadomość ujmuje czyjeś spostrzeżenia. W tym właśnie miejscu, w którym „,zwykły człowiek" biernie odnotowuje strumień doznań, Przyboś aktywnie je postrzega, analizuje i ukazuje jako materiał, z którego człowiek tworzy świat zewnętrzny i tka swoje życie. Jak pisze Janusz Sławiński, poeta ten konstruuje rzeczy $\mathrm{z}$ aktualnego postrzeżenia, któremu zwykle towarzyszy przypominanie i wyobrażanie $^{14}$. Celem tych dążeń jest - jak sądzę - poszukiwanie prawdy o świecie i prawdy o człowieku, którą Przyboś chce wydobyć z tego, co bezpośrednio człowiekowi dostępne: z wrażeń, z ich przetworzenia, z danych świadomości. Powracający u Przybosia obraz tęczy zyskuje w moich oczach wyraz symboliczny: podobnie jak w późnej twórczości Słowackiego, której Przyboś był admiratorem i znawcą, tęcza jest znakiem rozszczepienia świata w ludzkim poznaniu zmysłowym, ale też znakiem scalenia go w poznaniu wykraczającym poza dane zmysłów ku wyższej jedności, którą dla Przybosia (choć nie dla Słowackiego) jest świadomość.

Uporczywa praca Przybosia nad świadomą konstrukcją świata zewnętrznego jest także samotworzeniem, to znaczy utwierdzeniem swego istnienia w świadomości ${ }^{15}$. Praca ta ma aspekt moralny. Świat i człowiek u Przybosia musi się dopiero ukształtować, wydobywając się z bezkształtnej substancji wrażeń własną mocą. To świadomość, obejmująca w akcie kreacyjnym swoje własne akty - czyni świat światem, a człowieka - człowiekiem. Praca świadomości na jej wyższych poziomach jest zwycięstwem człowieka nad przypadkowością danych wchodzących w pole świadomości, nad ograniczeniem własnego czy czyjegoś doświadczenia, które zawsze obejmuje tylko wycinek rzeczywistości, a zwłaszcza nad chaosem ludzkiego strumienia świadomości.

${ }^{14}$ Cf. Janusz Sławiński, Koncepcja języka poetyckiego Awangardy Krakowskiej (Wrocław: Ossolineum, 1965); Artur Sandauer, „Esteta czy Scyta? Albo robotnik wyobraźni. Rzecz o Julianie Przybosiu”, in idem, Poeci czterech pokoleń (Kraków: Wydawnictwo Literackie, 1977); Kazimierz Wyka, „Wola wymiernego kształtu”, in idem, Rzecz wyobraźni (Warszawa: PIW, 1959); Jerzy Kwiatkowski, Świat poetycki Juliana Przybosia (Warszawa: PIW, 1972); Edward Balcerzan, Liryka Juliana Przybosia (Warszawa: WSiP, 1989); Zdzisław Łapiński, "«Świat cały, jakże zamknąć go w źrenicy» (O kategoriach percepcyjnych w poezji Juliana Przybosia)", in Studia z historii i teorii poezji polskiej, ed. Michał Głowiński (Wrocław: Ossolineum, 1970), 292-294; Barbara Łazińska, Przyboś i romantycy (Warszawa: Anta, 2002); Stulecie Przybosia, ed. Stanisław Balbus et Edward Balcerzan (Poznań: Wydawnictwo Naukowe UAM, 2002) (zwłaszcza studium: Maria Delaperriére, Metafora horyzontu, czyli o powinowactwie sztuk $i$ fenomenologicznym widzeniu świata $w$ poezji Juliana Przybosia).

${ }^{15}$ Kazimierz Wyka wspomina Przybosia jako człowieka stale siebie samego projektującego. Wspomnienia o Julianie Przybosiu, ed. et intr. Janusz Sławiński (Warszawa: Ludowa Spółdzielnia Wydawnicza, 1976), 250. Barbara Łazińska łączy ten rys pracy poety nad sobą i swoim życiem z przemianą światopoglądową, która miała się - zdaniem badaczki - dokonać pod wpływem studiów nad filozofią genezyjską Juliusza Słowackiego. Cf. B. Łazińska, Przyboś i romantycy. 
Samopoznanie, towarzyszące poznaniu świata, wniknięcie w konstrukcję własnego ,ja” daje efekt uniesienia, wznoszenia się ponad ograniczenia zwykłego, biernego, na wpół świadomego trwania ${ }^{16}$. Taka konstrukcja jest dla Przybosia źródłem sensu. Sądzę - chociaż żadne pojęcie nigdy nie oddaje w pełni sensu metafory, że właśnie owo samopoznanie jest nazwane światłem w jego programowym wierszu.

\section{Człowiek bez granic}

[...] O, schwytać promień - to pojąć znaczenie: to tworzyć, to nadążyć temu, co mija, być rówieśnym jutrzence i nie starszym od zorzy!

Iść, iść dalej, przejść poza, nie minąć, lecz prześcignąć siebie,

być, być więcej o wszystkich, ze swej skóry czynić lustro cudzych marzeń!

$[\ldots]$

Posługiwać się jedynym,

ostrzonym na planecie przez dni i przez prace

narzędziem:

światłem,

jak dźwignią i spojrzeniem,

linią i myślą!

Idąc - rozstawać się z sobą, a spotykać ze wszystkim!

Tylko witając ludzi pojętych tak jasno,

że nawet nieobecni błyszczą,

jak gdyby mieli wschodzić jeszcze

i nie zagasnąć we wspomnieniu cieni,

tylko biegnąc w blasku niezliczonych oczu,

tylko lecąc we wciąż jasnym obłoku

pomyślanym $\mathrm{z}$ iskier,

świecąc -

będę,

a jestem:

jak opadnięty przez rój pszczół

kulawy,

gdy dyrda podskakując

i toczy, kręcąc, rudą głowę, postfigurację

kuli ziemskiej,

toczącej się przecież wokół

ścigającego słońce

- jak z jabłkiem nadkrólewskim z władzą wiedzy w ręce -

człowieka-słońca.

[Sytuacje liryczne, 221-223]

${ }^{16}$ Ten fragment pracy jest przetworzeniem fragmentu końcowego mojego artykułu pt. Człowiek-stońce $i$ stwarzanie świata w poezji Juliana Przybosia. Zmiany polegają na wprowadzeniu pojęcia samoświadomości w miejsce pojęcia świadomości i na zaakcentowaniu panowania, jakie dzięki samoświadomości człowiek uzyskuje sam nad sobą. 
W istocie opisywany przez krytyków „akt kreacyjny” jest u Przybosia afirmacją świadomości. Afirmacja świadomości jest zaś afirmacją istnienia. Za nią postępuje afirmacja sztuki, która daje poczucie intensywności istnienia, ponieważ czyni je w pełni świadomym.

\section{Stan poetycki}

Wiemy już, że można zwerbalizowany rezultat aktu samoświadomości ukazać jako przedmiot estetyczny. A czy można bezpośrednie dane swojej świadomości ujmować na poziomie metaświadomości i kwalifikować „od razu” jako przedmioty estetyczne? Czy „włożenie” jakiegoś wybranego fragmentu strumienia świadomości, jaki jest w tej chwili moim udziałem, w swoistą „ramę estetyczną”, czyniłoby ten fragment życia po prostu doświadczeniem estetycznym? Czy takie właśnie przeżywanie swoich wrażeń nie jest tym, co nazywa się chwilą poetycką? Być może to właśnie rozumienie poetyckości (czy tym samym literackości?) pojawia się w słynnym tekście Fryderyka Schlegla, proponującym nowe wtedy rozumienie poezji (nazywanej romantyczną) - jako stanu poetyckiego.

Poezja obejmuje wszystko, co tylko jest poetyczne, od wielkich systemów - z kolei zawierających w sobie liczne systemy sztuki - aż po westchnienie, pocałunek, który w nieuczonym śpiewie wyda z siebie rozmarzone dziecko. [...] Romantyczny sposób tworzenia jest jedynym, który jest czymś więcej niż sposobem, jest jak gdyby samą sztuką poetycką: bowiem w pewnym sensie wszelka poezja jest albo powinna być romantyczna ${ }^{17}$.

Wydaje się, że technika strumienia świadomości, którą Przyboś musiał znać choćby z własnych lektur, a która zresztą „wisiała w powietrzu”, była po prostu do wynalezienia przez każdego, kto wyczuwał puls rozwijającego się piśmiennictwa europejskiego, właśnie ona dała Przybosiowi sposób na przetwarzanie dowolnej chwili w chwile poetycką. Potrzeba było bowiem tylko zmiany nastawienia. Zamiast przeżywać coś, poddając się swojemu nurtowi wrażeń, można to zarazem obserwować na metapoziomie, wytwarzając już w punkcie wyjścia tę postawę wobec świata, którą na ogół uzyskuje się ex post, w chwili tworzenia. Ta podwójność widzenia, postrzeganie dane wraz ze świadomością tego spostrzegania, jeśli nie zniszczy swobody i naturalności tego doświadczenia, może z każdej dowolnej chwili uczynić czas nacechowany przeżyciem estetycznym. U Przybosia świadomości tego doświadczania towarzyszy jego afirmacja.

Przypuszczam, że ze względu na umiejętność zaprzęgnięcia świadomości do pracy w specjalnym, opisanym wyżej trybie, Przyboś mógł często przeżywać stan poetycki i że dążąc do jego utrwalenia mógł pisać teksty poetyckie. Ale każdy opis rzeczywistości dokonywany przez Przybosia jest niebywale odświeżający

${ }^{17}$ Friedrich Schlegel, „Fragmenty z «Athenäum»”, in Manifesty romantyzmu 1790-1930. Anglia, Niemcy, Francja, ed. Alina Kowalczykowa (Warszawa: PWN, 1995), 168-169. 
- dla twórcy i dla czytelnika. Nie zmieniając niczego - Przyboś wszystko czyni nowym. Najpierw czytelnikowi jego świat odbiera, gdy niszczy jego przyzwyczajenia percepcyjne, ale natychmiast mu go oddaje: na nowo zobaczony, jak po odzyskaniu wzroku. Świat powtórzony w kreacji poetyckiej, na nowo skonstruowany, dzięki stwarzającej refleksji staje się jakby czystszy, klarowniejszy, wyraźniejszy. Dlatego rozumieniu wiersza towarzyszy często ożywienie i radość. Im głębiej penetruje Przyboś swoją świadomością, im precyzyjniej operuje rylcem swojej wyobraźni, tym głębsze i radośniejsze jest przeżycie czytelnika. Doświadczenie natury poznawczej zyskuje tutaj również walor estetyczny. To, co jest głębiej poznane, precyzyjnie przedstawione, wywołuje także wrażenie piękna. Być może jest to po pierwsze piękno nie samego przedmiotu, który bywa czymś marnym i przypadkowym, lecz piękno samej mocy świadomości.

Konstrukcja staje się istotą poezji Przybosia, ponieważ demonstruje siłę świadomości i samoświadomości - jako sprawczą. Lecz nie świat jest stwarzany przez świadomość, lecz ona sama. Świadomość dźwiga i buduje siebie samą. Świadomość sama siebie przekracza, transcenduje. Na tym polega boska siła świadomości, która nie może stworzyć niczego, ale która nieustannie ożywia i podnosi samą siebie. To ona jest nadkrólewskim jabłkiem w ręce, znakiem panowania nad sobą i całym światem. To dzięki niej człowiek staje się królem-słońcem.

\section{Sztuka}

Zastanawiając się nad definicją dzieła sztuki, Stanisław Ossowski rezygnuje z poszukiwania powtarzalnego charakterystycznego zbioru cech, które można by przypisać wszystkim przedmiotom estetycznym, tak bardzo różnym, a zwraca się ku przeżyciu estetycznemu. O tym, czy coś należy do sztuki, decyduje nie przedmiot przedstawienia, ale sposób przedstawienia. Dzieło sztuki to przedmiot tak zorganizowany, że zachęca odbiorcę do zajęcia postawy estetycznej. Spośród wielu możliwych wyróżników doświadczenia estetycznego wybiera badacz - co bardzo rzadkie - „życie chwilą”, wspólne z grą (zabawą), i otwarcie wyznaje, że nie umie podać cechy, która odróżnia grę od sztuki ${ }^{18}$. I tu, i tu uczestnik wchodzi w sferę specyficznego odczuwania czasu, skupienia na tym, co aktualnie przeżywane, odnajdywanie przyjemności z kontemplacji tego, co jest prezentowane. Według Ossowskiego doświadczenie estetyczne nie ma charakteru subiektywnego, chociaż bardzo intensyfikuje istnienie odbiorcy - ponieważ jest zarazem spotkaniem $\mathrm{z}$ artystą, którego akt twórczy uobecnia się wobec widza, a także ze społecznością tych, którzy już owo dzieło oglądali lub mogą je oglądać, wchodząc w pewną realnie istniejącą wspólnotę ludzi posiadających kompetencję estetyczną.

${ }^{18}$ Motyw związania sztuki z grą pojawia się także u Hansa-Georga Gadamera w książce Aktualność piękna. Sztuka jako gra, symbol i święto, trans. Krystyna Krzemieniowa (Warszawa: Oficyna Naukowa, 1993). 
Według Ossowskiego można zajęć postawę estetyczną także wobec natury. Decyduje tu nie samo posiadanie lub nieposiadanie przez dany pejzaż cech estetycznie walentnych, ale raczej nastawienie na ich poszukiwanie. Sprzyja temu poszukiwaniu izolacja z rzeczywistości, którą w sztuce osiąga się poprzez przedstawienie obrazu danej rzeczy, a nie tej rzeczy. Dlatego każdy pejzaż robi inne wrażenie, gdy jest oglądany w naturze, a inny w przedstawieniu, choćby najbardziej realistycznym. Izolację zaznacza rama obrazu. W sensie abstrakcyjnym każde dzieło sztuki pojawia się $\mathrm{w}$ takiej izolującej je od rzeczywistości ramie, zwanej w uogólnieniu ramą estetyczną ${ }^{19}$.

Gdy przypomnimy sobie te dawne już myśli Ossowskiego, wciąż zresztą aktualne i świeże, w kontekście naszych rozważań o strumieniu świadomości, narzuca się możliwość zastosowania koncepcji estetyka do tej właśnie techniki. Gdyby ująć strumień świadomości jako część natury, a technikę strumienia świadomości jako przedstawienie tej właśnie części natury przez świadomość, która jest w stanie wytworzyć ową potrzebną do zaistnienia percepcji estetycznej izolację, to staje się jasne, że strumień świadomości może być także zaprezentowany jako przedmiot dany do kontemplacji estetycznej.

Czy to już wszystko, o czym nas poucza analiza techniki strumienia świadomości w kontekście rozważań Ossowskiego? Widać od razu, że w tej technice, pojawiającej się w dziejach sztuki bardzo późno, po wiekach jej rozwoju, jest coś więcej.

Zastanówmy się na przykład, co może oznaczać przetransponowanie strumienia świadomości w taki obszar jego obserwacji, że możliwe staje się właściwe przeżyciu estetycznemu, wskazane przez filozofa jako wyróżnik - „życie chwilą". Przecież - można by rzec - strumień świadomości to poniekąd właśnie „życie chwilą". Na czym więc polegałaby różnica? Musiałyby się tu nakładać czy współpracować dwa różne sposoby przeżywania czasu, co wymagałoby osobnego zbadania.

Ale nade wszystko musiałyby się tu ujawniać dwa różne sposoby istnienia i pracy świadomości: ten, który jest przedmiotem przedstawienia, i ten, który polega na jej przedstawianiu. Ten drugi nazwałam metapoziomem, ale zaczynam widzieć, że kwestia metapoziomu, aczkowiek bardzo ważna, jest zaledwie wstępem do wyjaśnienia sposobu istnienia przedmiotu estetycznego. Na razie jednak nie znajduję lepszej kategorii. Widzimy, że uruchomienie tego specyficznego metapoziomu przekształca ujęcie dowolnego przedmiotu w przedmiot estetyczny. Jest czymś zadziwiającym, że świadomość może w ten sposób ująć sama siebie, swoje własne działania, a może - swoje istnienie, nie prowadząc do swego uprzedmiotowienia, a przeciwnie - intensyfikując własną pracę, wyzwalając kreatywność, wznosząc się ponad ograniczenia bieżących doznań, pozwalając zaistnieć wewnętrznej wolności, wyzwalając możliwość sztuki.

${ }^{19}$ Stanisław Ossowski, Wybór pism estetycznych, ed. Bohdan Dziemidok (Kraków: Universitas, 2004). 
Zaryzykowałabym twierdzenie, że na wyzwoleniu w akcie artystycznym tej właśnie ekspandującej ku wyższym sposobom istnienia świadomości polega piękno każdego przedmiotu sztuki. W tym ujęciu, późny wynalazek stale rozwijającej się sztuki - technika strumienia świadomości - ujawniałaby samą istotę sztuki, opierającej się jedynie na akcie świadomości, co najmniej dwupoziomowym i złożonym wewnętrznie, lecz niejako nagim, pozbawionym podpór w postaci przedstawień innych przedmiotów.

\section{BETWEEN THE ACT OF CONSCIOUSNESS AND THE ACT OF SPEECH. STREAM OF CONSCIOUSNESS TECHNIQUE AS A METAPHOR OF ART}

\section{Su m m ary}

The subject of the article is an aesthetic experience in literary arts illustrated with the example of stream of consciousness used in poetic prose by Julian Przyboś in his cycle of poetry entitled Pióro $z$ ognia (A Feather Made of Fire, 1937). There are several kinds of the stream of consciousness technique, but the most interesting one is a direct written record of a character's thought process which usually takes the form of an interior monologue. Such record of the multitudinous thoughts and feelings which pass through the mind cannot by treated as a speech act because of the lack of an apparent organized form and because of the fact that the "speaker" is not addressing an audience or a third person. However this equivalent of thoughts can be treated in an aesthetic manner, on a special meta-level which is possible in aesthetic communication. Therefore, the following questions arise: is it possible to take someone's own stream of consciousness as a subject of that kind of aesthetic experience and then to treat everything forming part of consciousness as inspiration for certain aesthetic interest? Could it be similar to "progressive universal poetry" described by Friedrich Schlegel? Could a well-known definition of aesthetic experience by Stanisław Ossowski be a proper description of such attitude? In Ossowski's concept, the most important features of aesthetic experience are as follows: separating from our scientific interests and practical concerns, a certain "disinterested" attitude and a play which allows different perception of time i.e. "living in the moment". If we adopt that approach to the modern stream of consciousness technique it may transpire that the most important aspect of any aesthetic experience is not a certain feature of a given piece of art but a certain activity of consciousness which assumes a particular position to itself and finds pleasure in the feeling of its own power and activity. 